\title{
LEGAL AND INSTITUTIONAL ISSUES CONCERNING SETTLEMENTS EXTENSION THROUGH PARCELLING OPERATIONS
}

\author{
Maria Enache*, Constantin Enache
}

“Ion Mincu” University of Architecture and Urbanism, Bucharest, Romania

\begin{abstract}
This paper focuses on the legal and institutional aspects faced by practitioners during their professional actions. There are two situations: parcelling for private housing on private terrains promoted by private promoters and parcelling for young people housing on local council lands. Urban plans have been and still are facing the gloomy reality of suggested changes inside the legislation and methodology of approving the urbanism documentation, the LAP (Local Area Plan) and UDP (Urban Design Plan). In order to establish differentiated responsibilities for local administration and private developer (initiator of the Local Area Plan) regarding the ensuring of necessary resources so that the urban plan should be applied and without whose completion the building permit cannot be issued. To further illustrate the issues, a successful operation of building a 240 apartment housing development on 11.00 ha given in Chitila, Ilfov County is presented. The involved project partners were: Chitila Local Council which provided with the land and pledged to carry out the infrastructure works, architects' design office which produce the parcelling plan and provided the execution projects for a set of 6 types of buildings and the young beneficiaries
\end{abstract}

Key words: Parcelling, Urban extension, Housing, Infrastructure, Social.

Article Info: Manuscript Received: February 6, 2012; Revised: March 6, 2012; Accepted: March 25, 2012; Online: May 29,2012

\section{Introduction}

Concerns for the development of housing for people with low income in Romania can be traced back to the beginnings on the nineteenth century, when clusters of houses were built after a type-project in Cluj, for the employees of the church and financed by Reformed Church.

During the interwar period and before, our country was influenced by the great movements taking place throughout Europe for Low cost habitation. A series of regulations that would contribute to a harmonious and hygienic city was developed.

Thanks to a study by Cincinat Sfințescu, we have a complete picture of social housing until 1940 . Dwellings completed between 1900-1940 were built by two important companies: "The Cheap Housing Communal Society" and "The Autonomous House of Buildings". Dwellings were built after type projects on

\footnotetext{
* Corresponding author:

Address: "Ion Mincu" University of Architecture and Urbanism, str. Academiei 18-20, sector 1, 010014, Bucharest, Romania.

Telephone: +40741.076.760

Email: maria_urbezooo@yahoo.com
}

parcelling vary in size and scope. In 1910 the "Cheap Housing Law" was voted, a general one, on February 13 and a special one for the city of Bucharest on May 1910.

So, Romania had a wealthy tradition during the inter-war period concerning this matter, Bucharest has the parcelling in "Jianu", "Vatra Luminoasa", "Damaroaia - Bazilescu" etc. as testimony.

Limiting the growth of the area of the localities (between 1970-1989) to the area already occupied with buildings and concentrating the effort of investments almost exclusively on collective housing has led to losing the knowledge of arranging the parcelling on empty land through lack of use.

The parcelling, pursuing the organization of coherent districts, is no longer a preoccupation for the professional planners as well as for the administration and the owners of land, being replaced with operations of separate division for each land of some former agricultural plots situated on the outskirts of big cities. This leads to a lack of coherent, firm legislation and random, unorganized urban sprawl.

From among the wide variety of issues involved in Romania's urban expansion today, we are going to 
outline those features appertaining to the extension of the city built-up area through parcelling in two ways:

i) Parcelling for private housing on private lands promoted by private promoters;

ii) Parcelling for houses for young people on local council lands.

In both cases, our analysis focuses on those legal and institutional aspects we have encountered in our professional practice.

\section{Private housing parcelling of private terrains promoted by private promoters}

In order to understand the legal and institutional aspects, we are referring both on the European convention regarding the urban development, to which Romania has adhered, and the current Romanian methodology concerning the extension of localities trough parcelling operations.

The Leipzig Charter for sustainable European cities underlined the sustainable use of resources and a smart spatial and urban planning in order to avoid the urban sprawl (2007:4): 'an important basis for efficient and sustainable use of resources is a compact settlement structure. This can be achieved by spatial and urban planning, which prevents urban sprawl by strong control of land supply and of speculative development. The strategy of mixing housing, employment, education, supply and recreational use in urban neighbourhoods has proved to be especially sustainable'.

Analysing the current methodology in Romania concerning the extension of localities through parcelling operations, we found mainly approaches technical aspects such as: the nature of the terrain, the functional zoning, the accessibility, the urbantechnological equipment, and the coherence of spatial organization.

Within this context, we raised some critical points of views regarding the tasks and responsibilities of public administration, as well as those regarding the promoter.

There are neither financial analyses nor estimates regarding the tasks and responsibilities of public administration, as well as those regarding the promoter. Once the urban planner has found the technical solutions to ensure the stability of constructions, access, infrastructure (roads, urban utility networks), optimal density, the urban documentation is approved and one can jump directly to the alienation of parcels and permit requests.

This is the point in which the private urban actor (promoter, initiator of parcel) is no longer a partner with obligations to community represented by City
Hall (after he has earned the surplus value resulted from the modification of the terrain status and after he only pointed to what one should do to solve the problems posed by the new development). Thus, the City Hall has to discuss with a large number of applicants (buyers of parcels) spread over a vast territory; the city hall should ensure the infrastructure, the public equipment and pay for the necessary expropriations to implement the beforementioned actions.

The City Hall lack the appropriate resources and personnel and are left to administrate rather haphazardly the chaos triggered by urban documentation that, we have to admit, are done harmoniously. In fact, the chaos is generated by the fact that the planner ignores his obligations to discuss the following aspects: the real need of extension - the number of applications, statistical data, growth forecasts - ; the cost of infrastructure, planning of the public domain and further public equipment and the private promoter's (developer's) obligations resulting from the contract to provide equipment, without which the terrain cannot be included in the city built-up area, the construction cannot get a building permit, as well as the obligations of the City Hall;

\section{Equipment provision regulations}

We have deliberately chosen to discuss at the end the 'functional mixture between housing, working places, education, and the recreational use of urban zones', about which in the Leipzig Charter, the European ministers tasked with development agree that it has proven to be sustainable'.

Now, after the Systematization Law of 1974 and Norms of land occupation within the built up perimeters of urban localities, elaborated according to this act by the Committee for the Problems of Popular Councils, have been abrogated, it has not been replaced by more flexible forms, as it is, for instance, the 'Observer of Housing' in France, and thus the process of equipping with all sorts of amenities is exclusively done through mechanisms of market economy or subjectively decided by promoter, planner or authorizing authorities. In case of contention, there is no provision meant to objectively establish the size of equipment and the neighbouring land.

Thus, urban documentation renders a differentiated sale value of private land by its allotting or not of some larger or smaller areas for public equipment on the said land.

When the Local Area Plan covers areas of land larger than the promoter's (initiator's) parcel, absurd situations appear if such areas for green spaces, 
churches, schools, nurseries, are included on the lands belonging to different owners.

We chose an example of urban sprawl the town Mogosoaia, located in the northwest limit of Bucharest. (Fig 1)

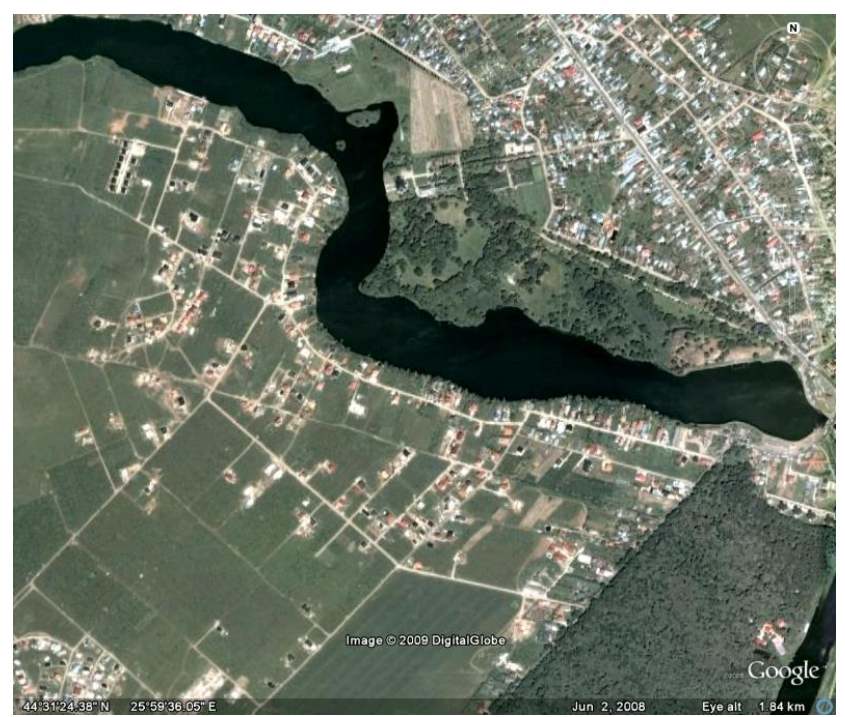

Figure 1 Aerial View of Mogoşoaia Source: Google Earth

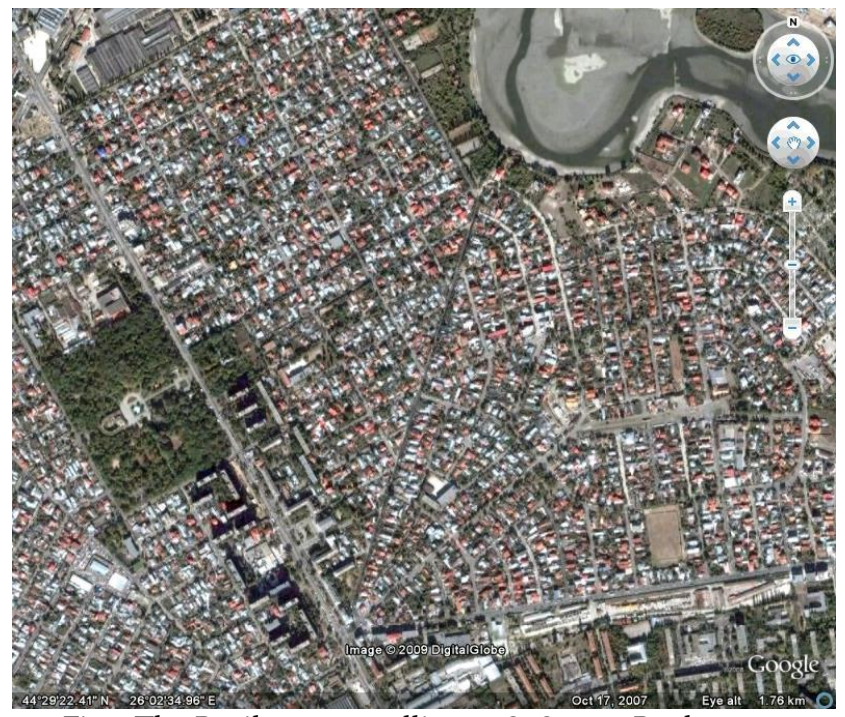

Fig 2 The Bazilescu parcelling - 1898-1913, Bucharest. Source: Google Earth

\section{Reality in the fields}

The current situation shows that the rule of development through parcelling, based on current the regulations, yields to the extension of our cities which could be defined as incoherent and completely different from the so-called 'compact structure of human settlements', as claimed by sustainable development.

Thus, it results into an uncontrolled development on a land which is too vast for the city hall to handle in matters resources of equipment and in which the dweller, a different person from the promoter of the work, is forced to live and use impracticable, muddy roads and incomplete equipment and utility networks.

The urban planner resorts to idealistic urban plans that could successfully qualify as utopias, since they lack the necessary resources to make them into real thing.

\section{Further arguments: the traditional way}

It is not now that Romania discovers the method of parcelling former farming lands. During the interwar period, such operations were done in most major cities, and we should look up to those results even today, like the successful parcelling "Bazilescu", "Vatra Luminoasa", "Ioanid" (Fig 2)

To exemplify, we have selected and attached the necessary stages that should have been gone through in order to operate a parcelling according to the 'Regulations for Building and Alignments of Bucharest Municipality' in 1939, which was only made possible due to the Law for the Organization of Bucharest, of March 4, 1939.

We have emphasized the stages that miss from the current regulations, a reason for our recurrent failures.

1. Obtaining the Certificate of alignment and building regulation from the City Hall (corresponding to today's Urban Certificate);

2. An application to obtain the authorization of parcelling, to which one should attach: the proposed parcelling plan drawn up by a certified professional and the specification of public works on the land or in its vicinity by pointing out the precise distance to property;

3. Approval from the Department of Planning and Systematization of the municipality showing that the proposal is in accordance with the Certificate of Alignment and Building Regulation;

4. Approval of the Commission that applies the Plan (corresponding to the Technical Urban Planning Commission);

5. Approval of Companies that administrate the water, power, gas utilities, which should stipulate if the parcelling can be equipped and, if the request is approved, they will draw up an estimate of the necessary work;

6. Issuing of the temporary parcelling permit, which specifies also the conditions to be met by the person who proposed the parcelling and the work to be executed on his expense with a view of obtaining the final permit.

7. Execution, by the proponents of parcelling, of the public works stipulated in the temporary permit as well as their verification by the City Hall and 
the companies that administrate the said public utility mains.

8. No parcelling is allowed on lands situated on the streets where the City Hall has not done any work yet, and to which the proposed parcelling could be connected, provided the owner executes or covers the costs of connection of the utilities to those in the city according to the conditions demanded by the companies administrating the public utility networks.

9. The areas planned for streets, cul-de-sacs and sidewalks, completely equipped with the necessary utility work, and which have been executed on the expense of the proponents of parcelling, should be given to the municipality by the owner for free.

10. When lands larger than 10,0oo sq $\mathrm{m}$ are parcelled, one should donate to the commune, besides the land for street widths, an area on which public facilities will be built (school, church, sport courts, etc). This area should be $10 \%$ of the whole land area - for those between 10,000 sq and 20,000 sq $\mathrm{m}$ - and $15 \%$ for those whose area is bigger than 20,000 sq $\mathrm{m}$ (according to art. 19, Law for the Organization of Bucharest Municipality of March 4, 1939).

11. Issuing of final parcelling permit.

12. The permit is issued for 2 years from the approval date, a period in which the owner should execute the work and the City Hall specialists should check every utility work included in the approved plans.

In our opinion, the extension of Mogoşoaia, according to Urban Local Plan, is a compact and coherent plan, but there is no guarantee that random development will take place (Figure 3 ).

In conclusion, to this section, we do not want to make this brief presentation sound like some hopeless lament. We will continue to dream fabulous urban plans and then face the gloomy reality, if we do not succeed soon enough to impose the following changes in the legislation and methodology of approving the urbanism documentation, the LAP (Local Area Plan) and UDP (Urban Design Plan). This is why we shall try to propose, within the confines of this analysis, several measures to be taken next:

1. To add to the current technical solutions demanded by the content framework the estimate of the costs of public works necessary to make the new development run smoothly (road infrastructure, equipping with necessary utility networks and connection to the locality mains);

2. To stipulate by law some minimal areas that should be preserved for facilities and public equipment that should be transferred to public administration without reimbursement;

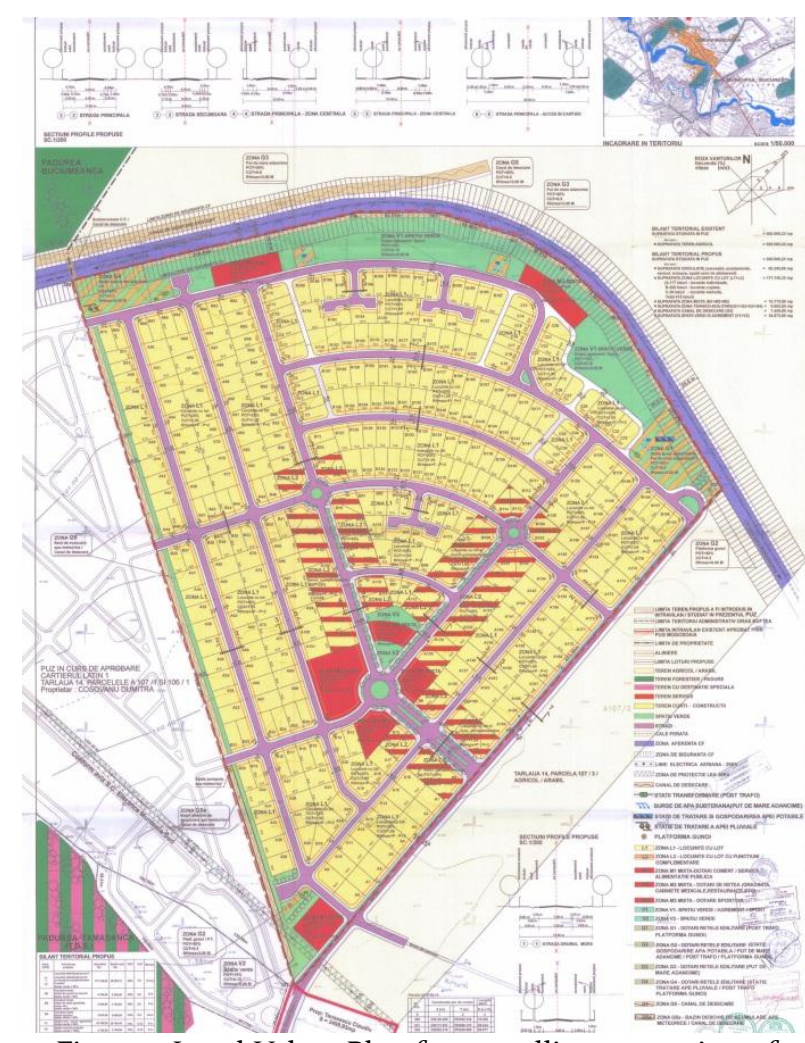

Figure 3 Local Urban Plan for parcelling, extension of Mogoşoaia within the built-up area. Source: Ilfov County Council.

3. To establish by law some differentiated responsibilities for local administration and private developer (initiator of the LAP) regarding the ensuring of necessary resources so that the urban plan should be applied and without whose completion the building permit cannot be issued.

4. To establish by law the issuing of the permit in stages in a raw: firstly, for the infrastructure work, and only when that is over, the buildings to be erected will be authorized.

\section{Local council lands and the parcelling process for young people housing}

The Law no. 156/2003, regarding the support given to young people to build their own house stipulates the way in which young people with the age between 18 and 35 could be given a piece of land of 250 to 500 sq $\mathrm{m}$ from the council land (the private property of the administrative-territorial units) [Art. 1].

According to the said law, the land, depending on the availability, can be used for free as long the privately owned house exists and by the decision of the Local Council of the village, city or municipality where the land is found. The beneficiaries have the obligation to start the building within one year from the moment the land has been given and comply with 
the legal provisions regarding the authorization of the building process.

Unfortunately, no deadlines are stipulated for the public authorities to fulfil their own obligations, and so we have already experienced absurd situations in Henri Coandă Housing Estate, Bucharest, that cannot be inhabited because no utility works have been done since its completion.

In the following paragraphs, we are going to describe an operation of building a 240 apartment housing development on $\mathbf{1 1 . 0 0}$ ha given in Chitila, Ilfov County (Figure 4).

Chitila is a small town with a population of about 12,500 inhabitants located at the northwest limit of Bucharest .

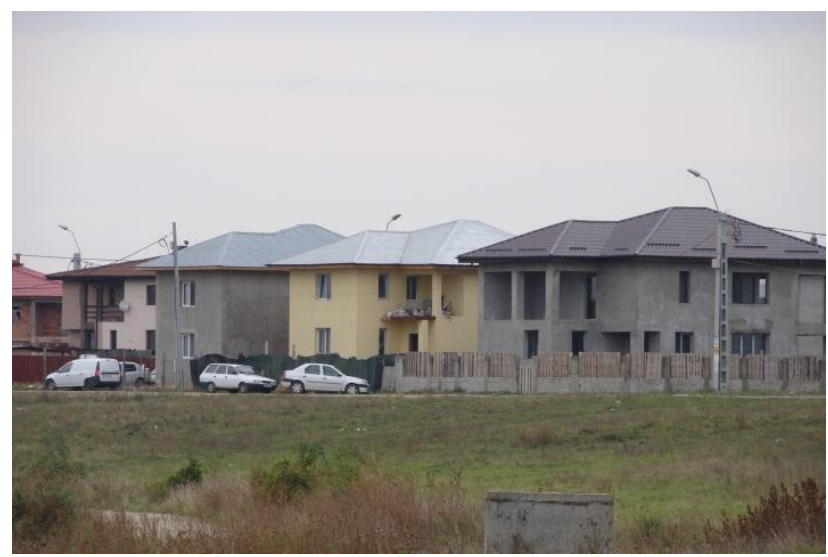

Figure 4. Overall view of the neighbourhood for the young people on Islaz Street, Chitila (Photograph's author Maria Enache)

The project partners were as follows: Chitila Local Council that gave the land and pledged to carry out the infrastructure works, our design office that did the parcelling plan and provided the execution projects for a set of 6 types of buildings and the young beneficiaries that were to build their houses on their own by complying with the regulation.

The design team was composed of the architects Maria Enache, Angelica Stan, and Constantin Enache. The land given by the Local Council is placed in an extremely attractive landscape. It is situated close to the current centre of Chitila town (where the City Hall, the Police Station, the school, church, and the cultural centre are located), in a particularly beautiful natural setting, on the border of the Saulei Valley. Thus, from the start, the location has eliminated the danger of social exclusion (Figure5).

The overall organization of parcelling implies some important aspects regarding the compact development of Chitila and the functional mixture in order to preserve the land for urban equipment. The main objectives of parcelling organization are:

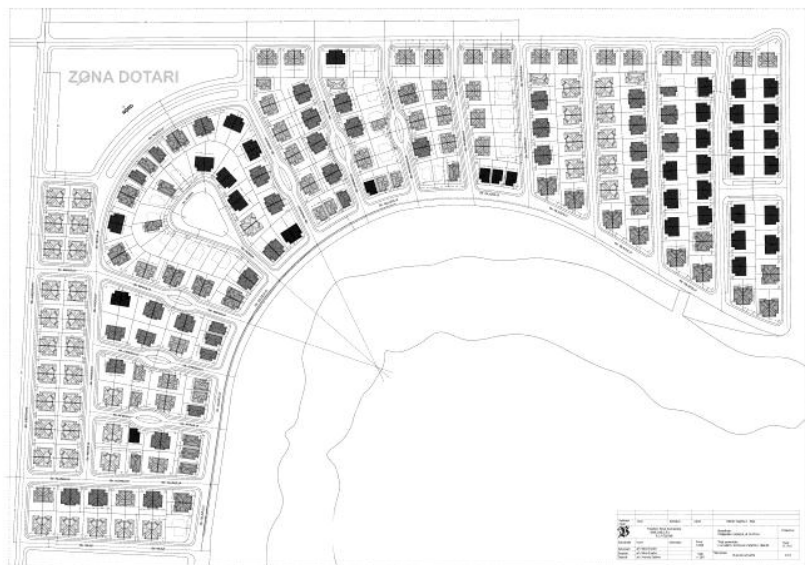

Figure 5. Plan of the social housing development for young people, Chitila (Authors source)

- The ensuring of a compact development of Chitila (approx. 12,500 inhabitants) (Figure 6);

- The natural integration within the existing hearth of Chitila by continuing the street fabric and maintaining direct connections with the central area;

- The directly connection to several parcels that possess favourable elements of natural environment by following a fan-like display of streets to the Saulei Valley;

- The creation of a necessary and desired functional mixture by preserving an important piece of land for collective facilities or equipment.

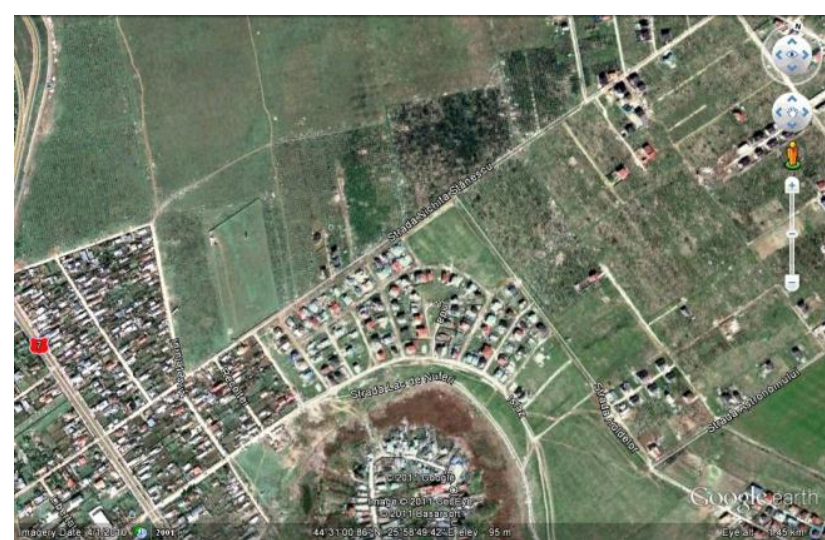

Figure 6. Aerial photograph of the ensemble (the first stage) illustrating the compact development with the participation of Local Council as partner Source: Google Earth

The percentage of occupied lands with various uses from the total area of 16.7 ha is the following: streets and sidewalks: 3.34 ha; public green spaces: 2.95 ha; preserved land for various facilities and equipment: 1.21 ha; total amount of public land is 7.5 ha, which is about $45 \%$.

The overall idea of the architectural project had pursued some major lines such as: 
- the simplicity that could allow the beneficiary to build on their own with branded, accessible materials;

- the chance to follow a certain typology able to render unity to the ensemble;

- the possibility to follow the regional expression of the typical Danube house with low pitched sweeping roof and a veranda that can help a smooth relation between interior and exterior and enhance it at the same time, as well as materials of specific colours (white plaster for walls, wood for carpentry, parapet, and soffit);

- what is more important, it is a house that can develop once the family grows.

As compared to the type of social housing, "inwaiting", which is rented to young families for a short period of time, until they save enough money to buy, this arrangement allowing land to be given to someone to build a house confers a degree of solidity through time.

To help the beneficiary, whose budgets are quite fragile, we have proposed a kind of house that can develop by starting from a minimal nucleus of 2 rooms and can extend up to 4-5 rooms.

In our opinion, its major advantage is that it can prevent the development of the area into a "poor" neighbourhood and help, instead, the evolution of social mixture.

\section{Research findings during the operation progress and conclusions}

Five years from its beginning, the operation is almost completed. Over 80\% (187) from the proposed houses are in advanced stages of execution, and many even inhabited. So far, the Local Council has only cleared the vegetation layer, spread one of rubble and has connected the power and water mains. The sewerage of waste water system and asphalting of roads are being carried on.

From the total amount of authorized houses (187) only 57 (about 30\%) have started from the minimal nucleus of 2 rooms, while the rest have developed as follows: 46 houses with 3 rooms (24\%); 61 houses with 4 rooms $(31 \%) ; 23$ houses with 5 rooms (12\%). Some of the beneficiaries who started with 4 and 5 rooms $(43 \%)$ had family support, while others had already solid budgets, which points to the mixed social status of the neighbourhood.

Some of the young people have started to build their houses but stopped at various stages of execution, while others chose to sell them. Even if by selling some of the houses will be owned by other users than those who had been given the land initially, some positive aspects should be underlined: the social mixture of the neighbourhood, the avoidance of social exclusion as well as the fact that young families with lower incomes who could not build their own houses earned quite a good amount of money from selling theirs at a good price, which allowed them to buy a modest or less favourably located house or rent one. Although the land and the authorization project have been given for free, there are cases, fortunately only few, of severe breach of the project requisites by moving $0.8 \mathrm{~m}$ from the property limit as to the blind wall and the change of the roof shape by building an additional garret.

For the time being, this is not an operation that could impress one through some stunning architectural forms but it shows a discreet, calm pattern that will reach its goal by better integrating a housing development into a locality and establishing a good relationship with the built environment, not to mention the social and functional mixture and overall harmony. We will see if the development of this neighbourhood will prove or not the solidity of this beginning.

The fact that public authorities have complied with their obligations is indeed a successful aspect. Today, the neighbourhood is almost completed and the extension with 120 more parcels is underway. The fact that the parcels were offered as a package with a design catalogue helped the coherence and the rapid start of the operation.

\section{References}

Bucharest Mayoralty 1935, Master Plan of Bucharest, May 9. Bucharest Mayoralty 1939, Building and Alignment Regulation for the City of Bucharest.

Chitila County Council, 2004, Local Area Plan, Social Housing for young people, Islaz Street.

Enache, M 2009, Locuință socială, Editura Universitară Ion Mincu.

EU Member states, The Leipzig Charter for European sustainable cities, Leipzig on 24-25 May, 2007 http://www.infocooperare.ro

Ilfov County Council, Local Area Plan for parcelling, extension of Mogoşoaia, within the built-up area.

Lascu, N 2011, Bulevarde bucureştene, Editura Simetria.

Machedon, L \& Scoffham, E 1999, Romanian Modernism, The Architecture of Bucharest, 1920-1940, MIT Press, Cambridge Massachusetts, London, pg. 104-105

Patrulius, R 1975, Locuința în timp și spatiu, Editura Tehnică, București.

Romanian Government 1939, Bucharest Law organization, Official Gazette, No 54 of March 4.

Romanian Government 1974, Law No 58 1974, Systematization Law, Official Gazette, No 135 of November 1.

Romanian Government 2003, Law no. 15/2003, Official Gazette no. 34 of January 22.

Woinaroschi, C 2007, Lotizarea și parcul Ioanid, Editura Simetria 